\title{
Caddo Ceramic Vessels from the W. J. Barnett Site (41SM2), Smith County, Texas
}

Timothy K. Perttula

Heritage Research Center, Stephen F. Austin State University

Follow this and additional works at: https://scholarworks.sfasu.edu/ita

Part of the American Material Culture Commons, Archaeological Anthropology Commons, Environmental Studies Commons, Other American Studies Commons, Other Arts and Humanities Commons, Other History of Art, Architecture, and Archaeology Commons, and the United States History Commons

Tell us how this article helped you.

This Article is brought to you for free and open access by the Center for Regional Heritage Research at SFA ScholarWorks. It has been accepted for inclusion in Index of Texas Archaeology: Open Access Gray Literature from the Lone Star State by an authorized editor of SFA ScholarWorks. For more information, please contact cdsscholarworks@sfasu.edu. 


\section{Caddo Ceramic Vessels from the W. J. Barnett Site (41SM2), Smith County, Texas \\ Creative Commons License \\ (c) (1) \& 8}

This work is licensed under a Creative Commons Attribution-NonCommercial 4.0 International License 


\title{
Caddo Ceramic Vessels from the W. J. Barnett Site (41SM2), Smith County, Texas
}

\author{
Timothy K. Perttula
}

\section{INTRODUCTION}

Ancestral Caddo ceramic vessels were found along the bank of an eroded ditch in the early 1930s at the W. J. Barnett site (41SM2). They were purchased by The University of Texas about 1935. The site is in the uplands about $6 \mathrm{~km}$ south of the Sabine River floodplain and ca. $2 \mathrm{~km}$ east of the Jamestown (41SM54) mound center.



Figure 1. The location of the W. J. Barnett site (41SM2) in East Texas. 


\section{Vessel Documentation}

There are two ancestral Caddo ceramic vessels in the collections from the W. J. Barnett site at the Texas Archeological Research Laboratory at the University of Texas at Austin (TARL). One is a plain grog-tempered bowl with an interior thickened rim and the other is a Poynor Engraved bottle.

SITE NAME OR SITE NUMBER: W. J. Barnett

VESSEL NO.: 1

VESSEL FORM: Bowl with an interior thickened rim

NON-PLASTICS AND PASTE: grog

RIM AND LIP FORM: Direct rim and rounded lip

CORE COLOR: $\mathrm{G}$ (fired in a reducing environment and cooled in the open air)

INTERIOR SURFACE COLOR: grayish-brown

EXTERIOR SURFACE COLOR: yellowish-brown; fire clouds on the rim, body, and base

WALL THICKNESS (IN MM): rim, $5.3 \mathrm{~mm}$

INTERIOR SURFACE TREATMENT: none

EXTERIOR SURFACE TREATMENT: smoothed

HEIGHT (IN CM): 9.1

ORIFICE DIAMETER (IN CM): 15.7

DIAMETER AT BOTTOM OF RIM OR NECK (IN CM): N/A

BASE DIAMETER (IN CM) AND SHAPE OF BASE: 7.5; circular and flat

ESTIMATED VOLUME (IN LITERS): 0.3

DECORATION (INCLUDING MOTIF AND ELEMENTS WHEN APPARENT): Plain

PIGMENT USE AND LOCATION ON VESSEL: none

TYPE AND VARIETY (IF KNOWN): Unidentified plain ware 
SITE NAME OR SITE NUMBER: W. J. Barnett

VESSEL NO.: 2

VESSEL FORM: Bottle with a carinated body

NON-PLASTICS AND PASTE: grog

RIM AND LIP FORM: Direct rim and rounded lip

CORE COLOR: $\mathrm{G}$ (fired in a reducing environment and cooled in the open air)

INTERIOR SURFACE COLOR: dark grayish-brown

EXTERIOR SURFACE COLOR: reddish-brown

WALL THICKNESS (IN MM): rim, $6.2 \mathrm{~mm}$

INTERIOR SURFACE

TREATMENT: none

EXTERIOR SURFACE

TREATMENT: none

HEIGHT (IN CM): 22.1

ORIFICE DIAMETER

(IN CM): 4.0

DIAMETER AT BOTTOM

OF RIM OR NECK

(IN CM): 5.1; maximum body diameter is $16.0 \mathrm{~cm}$

BASE DIAMETER (IN CM) AND SHAPE

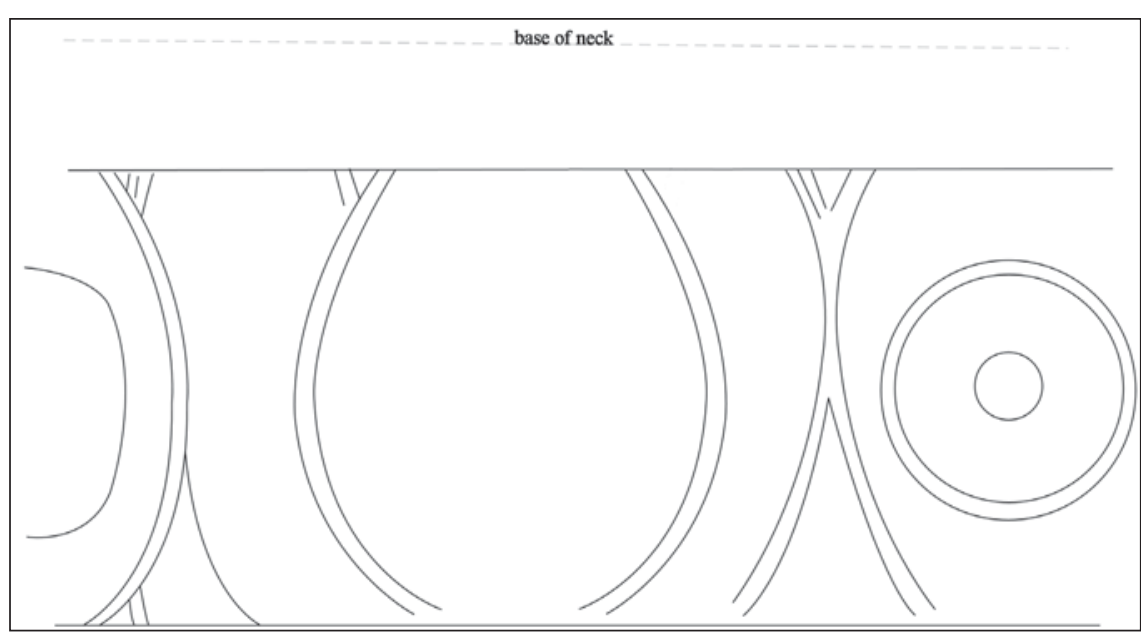

Figure 2. Poynor Engraved, var. Cook or var. Lang carinated bowl from the W. J. Barnett site (41SM2).

OF BASE: 6.0 ;

circular and flat

ESTIMATED VOLUME (IN LITERS): 0.5

DECORATION (INCLUDING MOTIF AND ELEMENTS WHEN APPARENT): The vessel body has an unknown number of large oval-shaped elements with hatched triangular corners, comparable to Poynor Engraved, var. Cook (Figure 2). One of the larger oval elements has a smaller set of circles within it, suggestive of a typological association with Poynor Engraved, var. Lang.

PIGMENT USE AND LOCATION ON VESSEL: none

TYPE AND VARIETY (IF KNOWN): Poynor Engraved, var. Cook or var. Lang (see Suhm and Jelks 1962:Plate 63j; Perttula 2011:Figure 6-64) 


\section{SUMMARY AND CONCLUSIONS}

There are two Caddo ceramic vessels from the W. J. Barrett site (41SM2) in the TARL collections. The one decorated vessel is a Poynor Engraved, var. Cook or var. Lang bottle. This bottle suggests that the W. J. Barrett site has Caddo burials that date from ca. A.D. 1400-1560 (see Perttula 2011:Table 6-37), and may be affiliated with Frankston phase Caddo communities in East Texas.

\section{ACKNOWLEDGEMENTS}

Sandra Hannum prepared Figure 1. I appreciate the access to the collections at TARL provided by Marybeth Tomka.

\section{REFERENCES CITED}

Perttula, T. K.

2011 The Ceramic Artifacts from the Lang Pasture Site (41AN38) and the Place of the Site within an Upper Neches River Basin Caddo Ceramic Tradition. In Archeological Investigations at the Lang Pasture Site (41AN38) in the Upper Neches River Basin of East Texas, assembled and edited by T. K. Perttula, D. B. Kelley, and R. A. Ricklis, pp. 145-320. Archeological Studies Program Report No. 129, Texas Department of Transportation, Environmental Affairs Division, Austin.

Suhm, D. A. and E. B. Jelks (editors)

1962 Handbook of Texas Archeology: Type Descriptions. Special Publication No. 1, Texas Archeological Society, and Bulletin No. 4, Texas Memorial Museum, Austin. Reprinted in 2009, Gustav's Library, Davenport, Iowa. 